\title{
REKONSTRUKSI KEDUDUKAN ANAK AKIBAT PERKAWINAN SIRRI PASCA PUTUSAN MAHKAMAH KONSTITUSI DENGAN PENDEKATAN HUKUM PROGRESIF ${ }^{1}$
}

\author{
Supriyadi \\ Fakultas Syariah Institut Agama Islam Negeri Kudus \\ Jalan Conge Ngembalrejo PO. Box 51 Kudus \\ arbysupriyadi@gmail.com
}

\begin{abstract}
The decision of the Constitutional Court in its development is not effective in its implementation. For this reason, it needs to be reconstructed in order to provide fair legal certainty. This research is a normative juridical research using secondary data which is analyzed qualitatively with a progressive legal approach. The conclusion in this study is that in progressive law children born as a result of sirri marriages have a different position from other illegitimate children. Forms of legal protection can be in the form of administrative records and other rights related to lineage, inheritance, marriage guardian, livelihood from his father.
\end{abstract}

Keywords: Reconstruction; Judgment; Sirri's Son.

\begin{abstract}
Abstrak
Putusan Mahkamah Konstitusi dalam perkembangannya tidak efektif dalam implementasinya. Untuk itu perlu direkonstruksi agar dapat memberikan kepastian hukum yang berkeadilan. Penelitian ini merupakan penelitian yuridis normatif dengan menggunakan data sekunder yang dianalisis secara kualitatif dengan pendekatan hukum progresif. Kesimpulan dalam penelitian ini adalah dalam hukum progresif anak yang lahir akibat perkawinan sirri mempunyai kedudukan yang berbeda dengan anak luar kawin lainnya. Bentuk perlindungan hukum dapat berupa pencatatan secara administratif dan hak-hak lain yang berkaitan dengan nasab, kewarisan, wali nikah, nafkah dari ayahnya.
\end{abstract}

Kata Kunci: Rekrontruksi; Putusan; Anak Sirri.

\section{A. Pendahuluan}

Perkawinan sirri merupakan perkawinan yang sah menurut agama, tetapi tidak sesuai dengan Undang-Undang Nomor 1 Tahun 1974 jo. Undang-Undang Nomor 16 Tahun 2019 tentang Perkawinan (UUP). Perkawinan yang tidak dicatatkan bertentangan dengan Pasal 2 UUP sehingga dapat dikatakan bahwa perkawinan yang tidak dicatatkan merupakan bentuk perkawinan yang secara formal tidak sah. Akibat perkawinan yang tidak sah maka anak yang dilahirkanpun mempunyai status tidak sah sebagaimana diatur Pasal 42 UUP. Sebelum putusan Mahkamah Konstitusi (MK) anak ini hanya mempunyai hubungan keperdataan dengan ibunya

\footnotetext{
${ }^{1}$ Hasil penelitian dengan pendekatan yuridis normatif yang dianalisis secara kualitatif.
} 
dan keluarganya. Namun pasca putusan MK RI Nomor 46/PUU-VIII/2010 tanggal 27 Pebruari 2012. Rumusan Pasal 43 ayat 1 UUP laki-laki sebagai ayahnya yang dapat dibuktikan berdasarkan ilmu pengetahuan dan teknologi dan/atau alat bukti lain menurut hukum mempunyai hubungan darah, termasuk hubungan perdata dengan keluarga ayahnya.

Pasca putusan Mahkamah Konstitusi tentu berimplikasi terhadap anak anak yang lahir di luar perkawinan. Anak yang lahir diluar perkawinan bisa karena perzinahan, pemerkosaan atau akibat dari perkawinan sirri. Perkawinan sirri sah menurut agama (Irfan Isami, 2017), sehingga harus direkonstruksi agar anak yang dilahirkan mendapat perlindungan hukum. Ketegasan MK ini pada prinsipnya merupakan pemberikan perlindungan hukum dan pemberikan kepastian hukum yang berkeadilan terhadap anak luar kawin meskipun perkawinan orang tua biologisnya masih dipertentangkan. Perlindungan hukum ini penting dalam rangka memberikan rasa keadilan terhadap anak yang lahir di luar perkawinan, Ketidakadilan ini terlebih terhadap anak yang lahir akibat perkawnan sirri yang secara agama diangap sah dan sosiologis dapat diterima oleh masyarakat tetapi secara administrasi belum ada kepastian hukum. Ketidakadilan ini terus berkembang dan anak sirri dianggap mempunyai kedudukan yang berbeda di mata hukum baik dalam hal kewarisan maupun dalam kaitanya dengan pencatatan administrasi. Anak akibat perkawinan sirri juga dipersamakan dengan anak luar kawin lainnya, sementara dalam kelahirannya mempunyai perbedaan dengan anak luar kawin. Anak perkawinan sirri kelahirannya diawali dengan prosesi perkawinan sedangkan anak luar kawin (zina) tidak didahului dengan proses tersebut.

Eksistensi anak yang lahir akibat perkawinan sirri dianggap sah secara agama sehingga berbeda dengan anak luar kawin lainnya tetapi secara administrasi belum memiliki kepastian hukum. Sehingga seringkali anak diterlantarkan atau ditinggalkan oleh ayahnya (Muksalmina, 2020). Di sisi lain anak dari perkawian sirri secara sosiologis dapat diterima masyarakat dalam arti keberadaan anak dan orang tuanya dianggap sebagai sebuah keluarga. Keluarga mereka bukan keluarga yang kumpul kebo tanpa ikatan apapun tetapi mereka sebagai keluarga yang keabsahannya diakui oleh agama. Mereka menikah menurut dengan ajaran islam yang berasal dari Allah dan RosulNya (Sri Asuti A Samad, 2020). Hal ini berbeda dengan anak luar kawin lainnya seperti anak yang lahir dari perzinahan atau akibat pemerkosaan. Anak anak yang lahir akibat perzinahan dipandang sebelah mata oleh masyarakat bahkan terkadang mereka dikucilkan. Oleh karena itu tidak tepat apabila anak dari perkawinan sirri dipersamakan dengan anak dari hasil perzinahan. Dalam kaitanya dengan putusan MK anak yang lahir akibat perkawinan sirri seharusmya mendapatkan perlindungan hukum baik secara materiil maupun secara hukum formal. Putusan MK dapat dijadikan dasar karena telah memberikan tafsir yang berisi, petunjuk atau pedoman yang secara hukum konstitusional (conditionally constitusional) (Pristiwiyanto, 2019). Pengakuan legal formal ini diperlukan karena anak dari perkawinan sirri dapat dinasabkan kepada ayahnya atau kalau meminjam istilah dari mahkamah konstitusi mereka bisa membuktikan secara ilmu pengetahuan dan teknologi diakui oleh ayah biologisnya. Artinya secara formal putusan mahkamah konstitusi ini mengikat terhadap anak akibat perkawinan sirri.

Dalam perspektif hukum progresif menjalankan hukum tidak sekedar teks dalam rumusan pasal pasal tetapi harus melihat semangat dari makna dari undang undang itu sendiri dan bagaimana manusia itu memaknainya (Satjipto Raharjo, 2006). Pemaknaan hukum tidak hanya hanya memaknai undang undang tetapi harus memberikan kebenaran dan keadilan. Pada prinsipnya hukum tidak bisa bekerja sendiri tetapi hukum membutuhkan aparatur penegak hukum yang menjalankannya atau orang dengan budaya hukumnya untuk menggerakkan hukum agar dapat berjalan secara efektif. Penegakan hukum tidak boleh dengan menggunakan kaca mata kuda tetapi juga harus menekankan pada faktor manusia karena hukum bekerja untuk manusia (I Gede AB Wirainata, 2009). Hukum progresif merupakan konsep hukum yang sarat dengan moralitas dengan tujuan kebahagiaan masyarakat, sehingga hukum progresif akan tampil untuk melindunngi kaum termarjinalkan. Hukum progresif terpanggil untuk memberikan 
perlindungan hukum agar Indonesia mempunyai hukum yang ideal (Sudjito, 2012). Berkaitan dengan putusan MK tentu anak sebagai akibat dari perkawinan sirri secara moral hukum harus mendapatkan perlindungan demi mewujudkan kepastian hukum dan keadilan. Untuk mewujudkan perlindungan hukum progresif terhadap anak dari perkawinan sirri maka perlu direkonstruksi tentang substansi hukum, struktur hukum dan kultur hukum dalam masyarakat (Friedman, 1984). Ketiga hal ini akan saling mempengaruhi untuk menciptakan efektifitas hukum agar sistem hukum dapat berjalan sesuai dengan yang dikehendaki.

Semangat Mahkamah Konstitusi ini tidak diimbangi dalam implementasinya. Sampai saat ini negara baik eksekutif maupun yudikatif belum mengimplementasikan dalam kehidupan bernegara hal ini terlihat belum adanya persamaan persepsi dalam mensikapi terhadap putusan mahkamah konstitusi tersebut. Hasil penelitian Budiarti menyimpulkan bahwa belum ada pengakuan pencatatan nama ayah di akta kelahiran oleh kantor kependudukan dan catatan sipil (Budiarti, 2017) dan para yurispun terkesan ragu ragu dalam memberikan putusan yang berkaitan dengan implementasi terhadap status anak yang lahir akibat perkawinan sirri dari orang tuanya. Hal ini dapat terlihat juga dalam putusan Mahkamah Agung nomor 329 K/AG/2018 yang intinya menyatakan bahwa anak yang lahir akibat perkawinan tidak sah merupakan anak tidak sah. Hasil penelitian Zaidah Nur Rosidah menyimpulkan hakim pengadilan negeri menganggap putusan Mahkamah Konstitusi bertentangan dengan Pasal 2 ayat (1) dan ayat (2) dan terhadap anak luar kawin telah diatur dalam Kitab Undang Undang Hukum Perdata (KUHPerdata). Sedangkan Hakim pengadilan agama menganggap putusan mahkamah konstitusi bertentangan dengan konsep nasab, wali nikah dan waris. Putusan pengadilan negeri Jakarta selatan nomor 586/Pdt.G/2014/PN Jaksel, yang pada intinya menyatakan anak luar kawin mempunyai hubungan perdata dengan ayah biologisnya melalui tes DNA (Monica Putri MC, 2016).

Dari hasil penelitian itu, terdapat perbedaan terhadap status anak pasca putusan $\mathrm{MK}$, sementara disisi lain satus anak perlu mendapatkan kepastian hukum yang berkeadilan. Tidak ada persamaan semangat untuk melindungi anak luar kawin sehingga perlu dilakukan rekonstruksi hukum terhadap norma norma hukum positif melalui pendekatan hukum progresif. Rekonstruksi hukum dengan pendekatan hukum progresif merupakan merupakan tulisan yang berbeda dengan tulisan tulisan sebelumnya dan belum pernah ada yang menulis. Rekonstruksi (Pius Partanto, 2001) hukum merupakan proses membangun kembali subtansi hukum, struktur hukum maupun kultur hukum yang telah ada agar berfungsi sebagaimana seharusnya. Semangat dalam rekonstruksi hukum ini adalah dalam rangka memberikan perlindungan terhadap anak akibat perkawinan sirri. Penataan kembali ini terinspirasi pemikiran Satjipto Rahardjo dengan hukum progesifnya yang mengemukakan bahwa "hukum untuk manusia", karena pada dasarnya manusia itu baik sehingga manusialah yang menentukan (Satjipto Rahardjo, 2008). Semula faktor hukum maka harus digeser menjadi faktor manusia Karena hukum bukan sesuatu yag mutlak tetapi selalu "dalam proses menjadi (law as process, in Law making)" yaitu dalam rangka mewujudkan hukum yang adil dan memberikan kesejahteran pada masyarakat (Mahmud Kesuma, 2009). Oleh karena itu tujuan penelitian ini adalah merekonstruksi dengan pendekatan hukum progresif tentang bentuk perlindungan hukum terhadap anak yang lahir sebagai akibat dari perkawinan sirri pasca putusan mahkamah konstitusi nomor 46/PUU-VIII/2010 dan untuk mengetahui kedudukan anak yang lahir sebagai akibat perkawinan sirri pasca putusan mahkamah Konstitusi nomor 46/PUU-VIII/2010.

\section{B. Metode Penelitian}

Penelitian ini merupakan penelitian kualitatif pendekatan Yuridis Normatif (Ronny Hanitijo Soemitro, 1984) dalam arti sempit yaitu merupakan penelitian dengan mempergunakan teknik dan metode yang biasa digunakan dalam penelitan hukum yaitu mendeskripsikan dan sinkronisasi peraturan perundangan yang berlaku (Winarno Surahmad, 1982). Dengan sumber data sekunder yang terdiri dari bahan hukum primer dan bahan hukum sekunder. Yang 
selanjutnya dianalisis secara kualitatif untuk mengungkap fenomena terhadap anak yang lahir dari perkawinan sirri.

Bahan hukum primer berupa putusan Mahkamah konstitusi Nomor 46/PUU-VIII/2010 dan peraturan perundangan yang melingkupinya dan bahan hukum sekunder berasal dari data-data yang di dapat dari buku buku, hasil penelitian, jurnal yang berhubungan dengan anak sebagai akibat perkawinan sirri.

\section{Hasil Penelitian dan Pembahasan}

\section{Perlindungan Hukum Progresif terhadap Anak Akibat Perkawinan Sirri}

Setidaknya ada 3 komponen yang terkandung dalam hukum sebagai sebuah sistem yang dibutuhkan dalam upaya melindungi anak akibat perkawinan sirri yaitu berupa struktur hukum, substansi hukum dan budaya hukum, kesemuanya harus saling mendukung terciptanya penegakan hukum yang baik dalam masyarakat (Warasih, 2005). Subtansi, struktur dan kultur akan saling mempengaruhi di dalam penegakan hukum artinya efektif atau tidaknya hukum dapat dilihat dari ketiganya Substansi, struktur dan kultur. Harapannya penegakan hukum dapat menciptakan kehidupan penuh kenyamanan dan menciptakan ketertiban serta kedamaian. Perlindungan hukum terhadap anak sirri ini penting karena perkawinan orang tuanya sah menurut agama (Sri Asuti A Samad, 2020) sehingga harus diberikan kejelasan tentang status si anak sirri. Pengakuan hukum tersebut untuk memberikan jaminan kepada anak sirri atas masa depannya, hal ini dimungkinkan sebab anak sirri juga mempunyai hak asasi manusia layaknya anak yang lain. Apabila tidak diberikan perlindungan hukum maka masa depan si anak akan terlantar dan tidak dapat berkembang karena terdapat beban psikologis. Beban psikologis ini jangan ditambah beban ekonomi dan beban hukum yang harus ditanggug oleh si anak. Oleh karena itu rekonstruksi hukum ini sebagai bagian untuk memberikan perlindungan hukum terhadap anak agar terkurangi beban beban yang yang harus ia tanggung.

Secara subtansi hukum, Putusan MK telah memberi pedoman anak sirri mendapat perlindungan hukum (Pristiwiyanto, 2019), bahkan secara tekstual rumusan dalam Pasal 43 ayat (1) telah di ubah sesuai kepentingan pemohon yang akhirnya berimplikasi pada masyarakat. Adanya putusan Mahkamah Konstitusi ini maka secara legal formal Pasal 43 (1) UU Nomor 1 Tahun 1974 jo. UU Nomor 16 Tahun 2019 tentang perkawinan, telah memberikan keadilan terhadap anak luar kawin khususnya anak sirri. Terhadap anak dari perkawian sirri justru akan lebih mudah di dalam membuktikannya karena orang tua mereka telah menikah secara sah menurut agama sehingga ayah biologisnya tentu telah mengakuiya, kecuali li'an. Hal ini berbeda apabila anak luar kawin dari hasil kumpul kebo (zina) yang tanpa diikat oleh perkawinan agama, maka apabila ingin ayah biologis mengakui maka si anak harus membuktikan dalil dalilnya yaitu dengan tes DNA. Pada dasarnya ada perbedaan mendasar antara anak luar kawin dari perkawinan sirri dengan anak dari perzinahan, anak sumbang. Secara sosiologis anak perkawinan sirri lebih mudah diterima dalam masyarakat, mereka tidak mendapatkan stigma buruk buruk dari masyarakat. Berbeda dengan anak dari perzinahan, anak sumbang tentu mendapatkan stigma buruk dari masyarakat, meskipun keberadaaan mereka karena kesalahan orang tuanya, seringkali diterlantarkan oleh ayahnya (Muksalmina, 2020).

Penelantaran anak luar kawin tentu tidak boleh terjadi karena sangat merugikan anak yang mengharapkan masa depan yang lebih baik sehingga harus mendapatkan perlindungan hukum. Pemberian perlindungan hukum diharapkan bisa menjembatani masyarakat dalam menyelesaikan masalah tersebut sehingga tercapai keadilan. Dalam kaitannya dengan anak dari perkawinan sirri maka peran struktur hukum akan sangat penting karena struktur hukumlah yang akan mengawal terhadap putusan MK tersebut. Struktur hukum meliputi aparatur penegah hukum, pelaksana undang undang (eksekutif) maupun pihak pihak yang terlibat dalam melakukan penegakan hukum agar lebih efektif. Aparatur penegak hukum juga harus memiliki komitmen dalam 
berkontribusi melindungai anak sirri. Aparatur penegak hukum dalam hal ini adalah eksekutif dan yudikatif yang menilai, memaknai dan sekaligus menjalan putusan mahkamah konstititusi. Oleh karena itu dalam mengkonstruksikan hukum maka harus tidak sekedar tekstual saja tetapi harus melihat semangat diputuskannya status anak luar kawin. Semangat putusan mahkamah konstitusi ini sejalan dengan hukum progresif. Semangat yang dijiwai hukum progresif ini akan memberikan kepastian hukum yang berkeadilan terhadap anak sirri.

Penegakan hukum terhadap putusan MK ini membutuhkan komitmen aparatur negara baik di eksekutif maupun di yudikatif. Semangat memberikan kepastian hukum terhadap anak dari perkawinan sirri merupakan sebuah keniscayaan karena mereka adalah yang akan melakukan eksekusi terhadap aturan hukum yang telah mengikat. Bagi eksekutif harus segera mengeluarkan keputusan sebagai pelaksanaan dari putusan $\mathrm{MK}$, baik dengan mengeluarkan peraturan pemerintah, keputusan presiden ataupun di tingkat daerah agar kedudukan anak dari perkawinan sirri menjadi jelas. Bagi yudikatif harus memberikan putusan yang tidak bertentangan dengan putusan MK. Putusan MK merupakan putusan yang mengikat tidak hanya hakim saja tetapi juga mengikat terhadap seluruh masyarakat. Keputusan MK harus didukung oleh sistem ketatanegaraan yang membutuhkan peran struktur hukum dan budaya hukum dalam masyarakat sehingga akan memberikan kepastian hukum (Jawahir Tantowi, 2001). Budaya hukum juga memegang peran penting dalam menciptakan efektifitas dibandingkan studi hukum yang hanya membicarakan historis saja (Lawrence M.Friedman \& Stewart Macaulay, 1977). Historisitas hukum akan dijadikan pengalaman berhukum masyarakat, pengalaman yang baik tentu harapannya pengalaman itu tidak akan terulang. Pengalaman yang baik tentu akan menjadi cara berhukum yang lebih baik. Pengalaman pengalaman berhukum dapat dijadikan sebagai bahan evaluasi terhadap bagaimana berhukum atau berperilaku yang berbudaya. Satjipto Rahardjo (Satjipto Rahardjo, 1980) menyatakan bahwa budaya hukum merupakan landasan berjalannya hukum positif karena berkaitan dengan nilai nilai atau pandangan yang dihayati oleh masyarakat.

Secara sosiologis anak dari perkawinan sirri dapat diterima oleh masyarakat. Masyarakat beranggapan anak anak tersebut secara agama telah sah, apalagi dalam kultur masyarakat tradisional di daerah tertentu banyak yang melakukan pernikahan sirri (Supriyadi, 2017) biasanya pernikahan tersebut dilakukan di depan seorang kyai. Pernikahannya ini seperti pernikahan di bawah tangan artinya pernikahannya tanpa dicatatkan di kantor urusan Agama oleh pejabat yang berwenang. Perkawinan yang dilakukan di depan kyai inilah oleh masyarakat dianggap telah sah, karena kyai adalah tokoh agama setempat yang sering dimaintai nasehat nasehat keagamaan. Inilah kemudian masyarakat lebih bisa menerima kehadiran anak sirri. Kyai sebagai tokoh masyarakat dijadikan teladan bagi masyarakat sekitar, sehingga nasehat nasehatnya akan dikuti juga oleh masyarakat, apalagi dalam masyarakat yang memiliki tipologi kharismatik tradisional. Oleh karena itu adalah wajar apabila seorang kyai yang menikahkan tanpa dicatatkan maka anak yang dilahirnya juga diterima oleh masyarakat. Anak ini mendapat pengakuan oleh masyarakat dalam pergaulan atau dalam berbagai acara yang dibuat oleh masyarakat.

Mahkamah Konstitusi putusannya bersifat general artinya tidak hanya berlaku bagi orang yang mengajukan permohonan uji materiil yang kasuistik individual hal ini sesuai dengan Pasal 56 ayat (3) jo Pasal 57 ayat (1) UUMK, sehingga putusan ini berlaku bagi seluruh masyarakat. Putusan ini mengikat juga terhadap para aparatur penegak hukum dan baik di lingkungan yudikatif maupun di lingkungan eksekutif. Tetapi terkadang para yuris ataupun eksekutif ada keragu raguan dalam mengimplementasikan putusan MK dengan berbagai alasan. Alasan yang sering muncul adalah putusan MK belum ditundaklanjuti dengan peraturan pemerintah atau peraturan teknis dalam pengadminitrasianya. Oleh karena itu dalam memahami putusan ini tidak sekedar secara substansi tetapi secara struktural harus mampu menjalankan norma yang telah mengikat. Secara kultural putusan MK harus dipahami dari berbagai aspek baik itu sosiologis, psikis. Tujuan akhirnya adalah memberikan keadilan dan kepastian hukum terhadap anak dari 
perkawina sirri. Hal ini lah yang dikehendaki dalam hukum progresif. Dengan pendekatan hukum progresif diharapkan akan tercapai keadilan sebagaimana yang dikehendaki masyarakat.

Dalam perspektif hukum progresif pencatatan perkawinan dapat dilihat dalam dua persepektif Pertama, Pencatatan perkawinan merupakan tanggung jawab negara sebagai sebuah negara demokrasi sebagaimana diatur dalam Pasal 28I ayat (4) dan ayat (5) UUD 1945. Kedua, Pencacatan merupakan bentuk administrasi agar mereka yang telah melangsungkan perkawinan mempunyai bukti otentik. Bukti otentik ini yang dapat digunakan untuk membuktikan bahwa telah terjadi perkawinan. Bukti otentik akan memberikan perlindungan kepada setiap pemegangnya sehingga hak hak yang terjadi setelah perkawinan akan terlindugi. Pembuktian ini juga dapat digunakan terhadap asal usul anak setelah perkawinan artinya terdapat kepastian hukum tentang status anak sebagaimana telah diatur dalam UUP. Tetapi apabila tidak mempunyai bukti akta perkawinan maka asal usul anak harus dibuktikan terlebih dahulu di pengadilan, hal ini diatur Pasal 55 UUP No. 1/1974. Asal usul anak yang orang tuanya tidak mempunyai akta otentik berupa akta nikah maka pengadilannya yang akan memutuskan(Boy Yendra Tamin, 2019). Untuk membuktikan ini membutuhkan waktu dan proses pengadilan sehingga status anak menjadi jelas.

Semangat mahkamah konstitusi adalah melindungi anak luar kawin artinya hubungan anak dengan orang tuanya dapat diperoleh melalui perkawinan dan dapat diperoleh di luar perkawinan dengan pembuktian dengan tes DNA antara si anak dengan orang tuanya khususnya dengan ayahnya. Hubungan anak dengan orang tuanya di luar perkawinan masih menjadi perdebatan baik dari kalangan akademisi, ulama maupun oleh masyarakat umum. Hal ini berbeda apabila dibandingkan dengan anak sirri (Supriyadi, 2016). Perbedaan ini karena anak yang lahir dari perkawinan sirri secara sosiologis dapat diterima oleh masyarakat dan secara agama telah memenuhi syarat rukunnya perkawinan. Semangat mahkamah konstitusi harus diikuti semangat para hakim perdata yang memberikan putusan yang berkaitan dengan anak akibat perkawinan sirri. Apabila hakim mempunyai semangat yang sama dengan mahkamah konstitusi maka potensial anak yang lahir dari perkawinan sirri sebagai anak yang sah menurut hukum. Pemikiran ini bertolak dari perkawinan orang tuanya adalah telah dilakukan menurut agama meskipun tidak dicatatkan. Sehingga dengan pengakuan dengan putusan oleh pengadilan ini maka status anak akan mendapatkan keadilan dan kepastian hukum.

Terdapat beberapa alternatif dalam penyelesaiannya secara hukum. Pertama, apabila perkawinan orang tua dari anak dilakukan sebelum berlakunya UUP maka dapat dilakukan dengan istbat nikah yang diputuskan oleh pengadilan. Dengan itsbat nikah maka perkawinan orang tuanya menjadi sah karena dapat dicatatkan hal ini tentu berakibat terhadap anak yang dilahirkan yaitu menjadi anak sah. Kedua, apabila perkawinan dilakukan setelah UUP maka hakim harus berani menggali nilai nilai yang hidup di masyarakat sebagaimana diatur oleh Pasal 5 ayat (1) Undang-Undang Nomor 48 Tahun 2009 tentang Kekuasaan Kehakiman yang intinya “ hakim wajib menggali, mengikuti dan memahami nilai nilai dan rasa keadilan yang hidup dalam masyarakat" Dengan penetapan melalui pengadilan baik memalui istbat nikah maupun dengan menggali hukum oleh hakim (rechvinding) maka kedudukan anak dari perkawinan siri dapat mempeoleh keadilan dan kepastian hukum.

Kepastian hukum ini yang dapat dijadikan dasar bagi kantor cacatan sipil dan kependudukan untuk mencantumkan status ayah dalam akta kelahiran. Secara agama perkawinan orang tuanya telah dilakukan menurut syarat dan rukunnya perkawinan maka terdapat nasab antara anak dengan ayahnya. Pencatatan perkawinan hanya merupakan pembuktian bahwa benar benar telah terjadi perkawinan (Neng Djubaidah, 2012). Hal ini yang berimplikasi terhadap anak yang lahir dari perkawinan sirri dalam melakukan pencatatan dalam akta kelahiran sebagaimana diatur Undang-Undang Nomor 23 Tahun 2006 tentang Administrasi Kependudukan Pasal 27 menyatakan "setiap kelahiran wajib dilaporkan oleh penduduk kepada instasi pelaksana setempat palingf lambat 60 hari sejak kelahiranya" Selanjutnya penerbitan akte kelahiran diatur 
dalam Pasal 52 ayat (1) Peraturan Presiden Nomor 25 Tahun 2008 yang pada intinya harus memenuhi syarat berupa : "surat kelahiran dari dokter/bidan, nama dan identitas saksi, kartu keluarga, kartu tanda penduduk orang tua dan kutipan akta nikah orang tua". Kutipan akta nikah orang tua inilah yang menyulitkan anak dari perkawinan sirri untuk memperoleh pengakuan. Apabila perkawinan orang tuanya dilakukan sebelum UUP maka dapat meminta istbat nikah ke pengadilan. Problem krusialnya adalah apabila perkawinan orang tua dilakukan setelah UUP dan tidak dicatatkan. Maka hal ini eksekutif dapat mengimplementasikan hukum progresif agar anak bisa memperoleh keadilan. Semagatnya haruslah sama dengan semangat mahkamah konstitusi yaitu semangat memberikan perlindungan hukum terhadap anak yang lahir dari perkawinan sirri.

Hal ini tentu berbeda dengan anak luar kawin seperti anak yang lahir dari perzinahan ataupun anak sumbang yang telah mendapat perlindungan hukum baik dari mahkamah konstitusi maupun dalam KUHPerdata. Anak luar kawin sebagaimana dalam pasal 280 KUHPerdata yang menyatakan "dengan pengakuan yang dilakukan terhadap seseorang anak luar kawin maka hubungan hukum antara anak dan bapak atau ibunya". Bahkan dalam Pasal 283 KUHPerdata menyatakan "anak luar kawin memperoleh hak waris dari orang tuanya meskipun tidak lebih banyak dari anak sah" Termasuk anak luar kawin dapat menikmati warisan dari hibah wasiat orang tuanya Pasal 908 KUHPerdata (J. Satrio, 2007). Demikian halnya dengan anak sumbang di mana perkawinan orang tuanya ada hubungan darah ataupun larangan perkawinan. Terhadap anak sumbang terdapat pengecualian sebagaimana diatur dalam Pasal 273 KUHPerdata Jo. Pasal 30 ayat (2) KUHPerdata dapat diakui sehingga menjadi anak sah, pengecualian ini tidak berlaku bagi anak hasil perzinahan. Bahkan seandainya anak sumbang karena sesuatu hal orang tuanya telah menikah dan dicatatkan menurut UUP yang kemudian diketahui adanya larangan perkawinan atau ada penghalang untuk melakukan perkawinan maka anak sumbang juga merupakan anak sah meskipun terjadi pembatalan perkawinan. Kedudukan anak dari pembatalan perkawinan tidak menyebabkan batalnya kedudukan anak sebagai anak sah meskipun perkawinan orang tuanya telah dibatalkan oleh pengadilan sebagaimana dalam Pasal 28 UUP (Feity Meiryana, 2018). Tidak menyebabkan putusnya hubungan antara orrang tua dan anak meskipun ada pembatalan diatur juga dalam Pasal 76 Kompilasi Hukum Islam yang menyatakan "batalnya perkawinan tidak memutuskan hubungan hukum antara anak dengan orang tuanya" Dengan demikian anak sirri harus dimaknai mempunyai hubungan hukum keperdataan dengan ayahnya sehingga membawa konsekuensi hukum yang berkaitan dengan hadhonah, nasab maupun kewarisannya, tentu hal ini harus harus ada pembuktiannya secara science meskipun telah memperoleh pengakuan dari ayah biologisnya.

\section{Rekonstruksi Kedudukan Anak Akibat Perkawinan Sirri}

Putusan mahkamah konstitusi tentu berimplikasi terhadap kedudukan anak akibat perkawinan sirri baik yang berkaitan dengan hak nafkah anak, wali nikah, nasab maupun terhadap hak kewarisan anak sirri. Secara normatif semangat putusan MK melindungi secara legal formal hukum terhadap anak sirri. Kedudukan anak akibat perkawinan sirri di samping berpedoman pada putusan MK juga melihat dari realitas sosial masyarakat yang lebih dapat menerima anak sirri dibanding dengan anak zina. Anak sirri dalam pandangan masyarakat dianggap seperti anak sah karena orang tuanya dinikahkan oleh tokoh agama setempat, sehingga dalam pandangan masyarakat anak ini juga harus diakui keberadaannya. Bahkan anak baik laki laki maupun perempuan berhak memperoleh warisan apabila ayah dan ibunya meninggal dunia (Didi Sukardi, 2015). Meskipun perkawinan orang tuanya masih dipersengketakan artinya terdapat perbedaan pendapat tentang sahya perkawinan sebagaimana dalam pasal 2 UUP. Pendapat pertama, perkawinan tanpa dicatatkan tetap sah alasanya pencatatan sama dengan pencatatan peristiwa penting lainnya yang harus dilakukan pencatatan seperti pencatatan kelahiran atau kematian sehingga pencatatan tidak menentukan keabsahan perkawinan tetapi 
hanya pencatatan administratif. Kedua, bahwa pasal 2 ayat (1) dan ayat (2) UUP adalah satu kesatuan sehingga perkawinan disamping dilakukan sesuai agama dan kepercayaan maka harus dilakukan pencatatan. Rumusann Pasal 2 ini tidak boleh saling meniadakan disamping itu pencacatan merupakan alat bukti otentik untuk membuktikan terjadinya peristiwa perkawinan (Supriyadi, 2015). Namun demikian dalam putusan MK telah menolak permohonan uji materiil terhadap Pasal 2 UUP yang intinya pemohon memohon kepada Mahkamah Konstitusi untuk menyatakan "sahnya perkawinan dilakukan menurut agama dan kepercayaannya tanpa kewajiban untuk dicatatkan”. Penolakan oleh MK terhadap Pasal 2 UUP menunjukan bahwa pasca putusan MK maka tiap tiap perkawinan wajib didaftarkan.

Mahkamah konstitusi dalam pertimbangannya memisahkan antara perkawinan yang tanpa dicatatkan dengan kedudukan anak luar kawin, artinya meskipun perkawinan orang tua masih disengketakan tetapi semangat untuk memberikan perlindungan anak luar kawin merupakan keniscayaan. Semangat inilah yang harus dikonsruksikan terhadap kedudukan anak dari perkawinan sirri. Sebenarnya anak luar kawin telah diatur dalam Pasal 280 KUHPerdata dan Pasal 863 KUHPerdata. Menurut KUHPerdata anak luar kawin terbagi menjadi tiga golongan yaitu anak luar kawin, anak zina dan anak sumbang. Anak luar kawin ini meliputi anak dari hasil hubungan antara perempuan dengan laki laki yang masing masing atau salah satu tidak mempunyai suami atau istri. Anak zina merupakan hasil hubungan dilakukan oleh perempuan dan laki laki yang salah satunya telah menikah dengan orang lain. Sedangkan anak sumbang merupakan hasil hubungan perempuan dan laki laki yang terdapat hubungan darah atau terdapat halangan perkawinan.

Apabila dicermati putusan MK maka mengandung penafsiran yang sangat luas jika dikaitkan dengan UUP, Pertama, anak sirri (memenuhi rumusan pasal 2 ayat (1) tetapi tidak sesuai dengan pasal 2 ayat (2). Kedua, anak yang lahir di luar perkawinan sirri misalnya anak zina, anak sumbang, anak hasil "kumpul kebo" tidak memenuhi rumusan pasal 2 ayat (1) dan ayat (2). Jika dilihat dari aspek "maqashid al-syari'ah" hal ini bertentangan dengan semangat "hifdz al-Nafs, hifdz al-Nasl dan hifdz al-Din". Yang prinsipnya memelihara dan memberikan perlindungan harus sesuai dengan agama. Tidak dibedakannya anak luar kawin dalam putusan MK ini lah yang kemudian Majelis Ulama Indonesia mengeluarkan fatwa MUI No. 11 Tahun 2012 tentang Kedudukan Anak Hasil Zina dan Perlakuan Terhadapnya yang dinyatakan bahwa "anak hasil zina tidak mempunyai hubungan nasab, wali nikah, waris dan nafaqoh dengan lelaki yang menyebabkan kelahirannya". Penolakan Majelis Ulama Indonesia tidak menyebutkan tentang anak sirri sehingga dapat dimaknai bahwa anak sirri mempunyai kedududukan yang berbeda dengan anak luar kawin lainnya. Putusan MK dianggap "over dosis". Artinya mahkamah konstitusi telah memasuki urusan agama yang sebenarnya bukan menjadi wilayahnya. Memutuskan sebuah norma hukum harus juga mempertimbangkan norma masyarakat agar hukum yang diciptakan dapat ditaati masyarakat. Hukum yang tidak sesuai dengan norma dalam masyarakat pasti akan ditolak oleh masyarakat atau setidaknya hukum tersebut tidak akan dapat berlaku secara efektif.

Perkawinan merupakan kebutuhan dasar manusia untuk membentuk rumah tangga yang bahagia berdasarkan Ketuhanan Yang Maha Esa (Tengku Erwinsyahbana, 2012). Perkawinan yang sesuai dengan agama maupun keyakinannya setidaknya telah sesuai juga dengan rumusan Pasal 2 ayat (1) UUP. Perkawinan ini seharusnya anak dapat memperoleh haknya yaitu nasab, wali nikah, waris maupun nafkah dari orang tuanya. Jika mencermati fatma MUI, tentu tidak didapatkan terhadap anak yang lahir karena perzinahan, anak sumbang maupun anak luar kawin lainnya. Kelebihan anak sirri adalah mereka lahir dari perkawinan menurut agama dan kepercayaannya meskipun tidak dicatatkan sebagaimana diamanatkan dalam pasal 2 ayat (2) UUP. Sebagai bentuk perlindungan hukum terhadap anak yang lahir akibat perkawinan sirri maka seharusnya mendapatkan status yang sama dengan anak sah dari orang tuanya baik dari ibu maupun dari ayahnya. 
Jika dalam hukum KUHPerdata terdapat perbedaan dalam hak kewarisan antara anak sah dan anak luar kawin maka terhadap anak akibat dari perkawinan sirri tidak demikian. Karena anak dari perkawinan sirri mempunyai kedudukan yang sama dengan anak sah. Apabila anak sah mendapatkan hak atas nasab, waris, wali nikah, nafkah dari ayahnya maka seharusnya anak dari perkawinan sirri juga demikian. Status kelahiran anak akibat perkawinan sirri tentu bukan kesalahan si anak tetapi kesalahan atau kelalaian orang tua yang tidak melakukan pencatatan perkawinan, sehingga kesalahan orang tua tidak dapat dibebankan kepada anak sirri. Dalam hal kewarisan anak dari perkawinan sirri juga mempunyai hak atas harta pewaris yang telah meninggal dunia (Islamiyati, 2015). Pemberian warisan dianggap mempunyai nilai ekonomis bagi ahli waris (Nur Aksin, Rahmat Robi Waliansyah, 2020). Putusan MK harus dipahami secara lex generalis oleh karena itu perlu aturan pelaksanaan demi memberikan perlindungan anak dari perkawinan sirri yang akan menjustifikasi terhadap anak yang dilahirkan dari perkawinan yang tidak dicatatkan tetapi secara agama dinyatakan sah.

\section{Simpulan dan Saran}

Dari data-data yang telah dianalisis dalam hasil penelitian ini maka dapat disimpulkan sebagai berikut: Pertama, pendekatan hukum progresif memberikan perlindungan hukum baik secara yuridis maupun sosiologis terhadap anak yang lahir akibat perkawinan sirri. Secara yuridis pasca putusan mahkamah konstitusi, anak yang lahir akibat perkawinan mempunyai kedudukan yang sama dengan anak sah sehingga mempunyai hak dan kewajiban yang sama di muka hukum. Secara sosiologis anak tersebut dapat diterima oleh masyarakat tanpa dibedakan status perkawinan orangtuanya. Oleh karena itu secara administrasi berhak diperlakukan sama dengan anak sah khususnya dalam pencatatan administrasi kependudukan dan akta kelahirannya.

Kedua, pasca-putusan mahkamah konstitusi kedudukan anak yang lahir sebagai akibat perkawinan sirri berbeda dengan anak luar kawin lainnya baik berkaitan nafkah, wali nikah, nasab maupun warisan. Anak yang lahir akibat perkawinan sirri berhak memperoleh hak hak tersebut dari orang tuanya baik dari keluarga ibunya ataupun ayahnya. Meskipun perkawinan

sirri tidak dicatatkan tetapi perkawinan mereka secara agama telah sesuai dengan syarat dan rukunnya perkawinan sehingga mempunyai hubungan nasab dengan ayahnya. Hubungan nasab inilah yang berimplikasi terhadap status anak yang dilahirkan termasuk hak kewarisannya. Hak hak anak akibat perkawinan sirri dapat dipersamakan dengan anak sah dengan tidak membedakan status perkawinan dari orang tuanya.

\section{DAFTAR PUSTAKA}

Boy Yendra Tamin. (2019). Kedudukan Anak Diluar Perkawinanan (Perkawinan Bawah Tangan) Pasca Putusan Mahkamah Konstitusi Nomor 46/PUU-VIII/2010. Dunia Hukum.

Budiarti. (2017). Implementasi Putusan Mahkamah Konstitusi RI Nomor 46/PUU-VIII/2010 tentang status anak luar kawin dalam administrasi kependudukan. UIN Syarif Hidayatullah.

Didi Sukardi. (2015). Perolehan Hak Waris bagi Istri kedua, ketiga dan keempat: Pendekatan Ilmu dan Filsafat Hukum. Jurnal Masalah Masalah Hukum, Jilid 44(No. 2), 161.

Feity Meiryana. (2018). Tinjauan Hukum Islam Terhadap Nikah Fasid Dan Dan Dampaknya (Studi Putusan Terhadap Putusan Hakim Di Pengadilan Agama Bengkulu). QIYAS (Jurnal Hukum Islam Dan Peradilan), Vol 3(No 1), 48.

Friedman, L. M. (1984). What Is a Legal System. American Law. W.W. Norton \& Company.

I Gede AB Wirainata. (2009). Hukum Bangun Teori dan Telaah Dalam Implementasinya. Kompas. 
Irfan Isami. (2017). Perkawinan Dibawah Tangan ( Kawin Sirri) Dan Akibat Hukumnya. ADIL Jurnal Hukum, 8(1), 71.

Islamiyati. (2015). Analisis Asas Keadilan Pada Pada Pembagian Harta Warisan Menurut Hukum Islam. Masalah Masalah Hukum UNDIP, Vol 44(1), 107.

J. Satrio. (2007). Hukum Keluarga Tentang Kedudukan Anak Dalam Undang Undang. Sinar Grafika.

Jawahir Tantowi. (2001). Budaya Hukum dan Kekerasan Dalam Dinamika Politik Indonesia. UII Press.

Lawrence M.Friedman \& Stewart Macaulay. (1977). Law and behavioral Science. The BobbsMemill Company Inc.

Mahmud Kesuma. (2009). Menyelami Semangat Hukum Progresif. LSHP Indonesia.

Monica Putri MC. (2016). Implementasi Putusan Mahkamah Konstitusi nomor 46/PUUVIII/2010 terhadap anak yang lahir di luar perkawinan (putusan sengketa antara Jessica Iskandar dengan Ludwig Frans Willibald di Pengadilan Negeri Jakarta Selatan nomor 586/Pdt.G/2014/PN Jaksel). Jurnal Privat Law, Vol IV No.(januari-Juni), 45.

Muksalmina. (2020). Pernikahan Sirri Dalam Perspektif Hukum Islam Dan Hukum Positif. Jurnal JIP (Jurnal Inovasi Penelitian), Vol.1(No. 2 Juli), 54.

Neng Djubaidah. (2012). Pencatatan perkawinan dan perkawinan tidak dicatat: menurut hukum tertulis di Indonesia dan Hukum Islam. Sinar Grafika.

Nur Aksin, Rahmat Robi Waliansyah, N. D. S. (2020). Sistem Pakar Pembagian Harta Waris Menurut Hukum Islam. Walisongo Journal of Information Technology, Vol 2(No.2), 116.

Pius Partanto, M. D. B. (2001). Rekonstrusi Merupakan Penyusunan Kembali, Kamus Ilmiah Popular. PT Arkala.

Pristiwiyanto. (2019). Status Anak Luar Kawin Pasca Putusan MK No. 46/PUU-VIII/2010. Jurnal Fikroh, 12(1), 22.

Ronny Hanitijo Soemitro. (1984). Metodologi Penelitian Hukum. Ghalia Indonesia Jakarta.

Satjipto Rahardjo. (1980). Hukum dan Masyarakat. Angkasa.

Satjipto Rahardjo. (2008). Membedah Hukum Progresif. Buku Kompas.

Satjipto Raharjo. (2006). Membedah hukum progresif. PT Kompas.

Sri Asuti A Samad, M. (2020). Adat Pernikahan Dan Nilai Nilai Islami Dalam Masyarakat Aceh Menurut Hukum Islam. Jurnal Wl-Usrah; Jurnal Hukum Keluarga, Vol.3 No 2(JuliDesember), 294.

Sudjito. (2012). Hukum Dalam Pelangi Kehidupan. Gadjah Mada University Press.

Supriyadi. (2015). Dasar Dasar Hukum Perdata Di Indonesia. Kiara Science.

Supriyadi. (2016). Rekonstruksi Kewarisan Anak Dari Perkawinan Sirri Di Pengadilan Agama. Ijtihad, Vol 16 No, 35.

Supriyadi. (2017). Perkawinan Sirri Dalam Perspektif Hukum Di Indonesia. Jurnal Yudisia, Vol 8 No.1(Juni), 2. 
Tengku Erwinsyahbana. (2012). Sistem Hukum Perkawinan Pada Negara Hukum Berdasarkan Pancasila. Ilmu Hukum, Vol 3(No.1), 166.

Warasih, E. (2005). Pranata Hukum Sebuah Telaah Sosiologis. PT. Suryandaru Utama.

Winarno Surahmad. (1982). Dasar Dan Teknik Reserch Metodologi Ilmiah. Tarsito. 